\title{
Larval development of the intertidal barnacles Chthamalus stellatus and Chthamalus montagui
}

\author{
M.T. Burrows, S.J. Hawkins* and A.J. Southward ${ }^{\dagger}$ \\ Dunstaffnage Marine Laboratory, PO Box 3, Oban, Argyll, PA34 4AD. *Division of Biodiversity and Ecology, School of Biological \\ Sciences, University of Southampton, Southampton, SO16 7PX. ${ }^{\dagger}$ Marine Biological Association, The Laboratory, Citadel Hill, \\ Plymouth, PL1 2PB
}

\begin{abstract}
Two recently-distinguished species of Chthamalus (Cirripedia) are found on rocky shores in the northeastern Atlantic: C. stellatus predominant on islands and headlands and C. montagui more abundant in bays. Larvae of the two species were produced in laboratory cultures to describe and compare the morphology and to allow identification in plankton samples. Nauplius larvae of C. stellatus are up to 30\% larger than those of C. montagui. Differences in setation are minor. The two species are easily distinguishable from the size and shape of the cephalic shield. Chthamalus stellatus has a subcircular shield with longer body processes in later stages while C. montagui is more ovoid. The former develop more slowly in culture than the latter. Chthamalus stellatus larvae in a culture at $19^{\circ} \mathrm{G}$ reached stage VI in $16 \mathrm{~d}$ compared to 11 d for larvae of C. montagui at the same temperature. The morphology and longer development time of C. stellatus larvae suggests adaptation to a more oceanic lifestyle and wider dispersal to reach more fragmented habitats than larvae of C. montagui.
\end{abstract}

\section{INTRODUCTION}

The two species of intertidal barnacles of the genus Chthamalus now recognized in the north-eastern Atlantic overlap considerably both in vertical zonation and in local and larger-scale geographical distributions (Southward, 1976). Similarity between adults of the two species delayed their recognition as species and with their wide co-occurrence prompted the question as to how the species could coexist (Crisp et al., 1981; Burrows et al., 1992). The first evidence for differences in biology is in the small differences in adult distribution: Chthamalus stellatus (Poli) predominates on exposed open ocean ('blue water') coasts, while Chthamalus montagui Southward is more abundant in embayed situations, where the water contains more particles in suspension. It has been suggested, however, that the major difference between the species producing the two different distribution patterns could be in the planktonic stages (Crisp et al., 1981). Duration of larval life, food items preferred and conditions preferred for larval settlement may all differ between the species.

Descriptions of the larvae of $C$. stellatus sensu lato of Darwin (1854) have been produced from various parts of the world. Only those from material collected in Europe, however, are likely to be of $C$. stellatus and $C$. montagui as currently recognized (from Britain: Groom, 1894; Bassindale, 1936; Mediterranean: Le Reste, 1965). While other workers have produced larvae of the two species (Jensen et al., 1994), the morphology, size and pattern of development of the naupliar stages remain undescribed. Chthamalus is often the most abundant genus of cirripede larvae in samples of plankton taken close inshore in mid summer (Burrows, 1988), and identification to species is highly desirable for any study of seasonality or dispersal of larval production.
The principal aim of this study was to describe and compare the morphology the larval stages of $C$. montagui and $C$. stellatus to enable identification of larvae of the two species from plankton samples. Relative rates of larval development were compared by culturing larvae of the two species in similar conditions in the laboratory. Differences in morphology and development times were assessed in terms of possible effects on recruitment to the sessile stage on the shore. Variation in the size of Chthamalus nauplii in the plankton was investigated throughout the reproductive season to determine the consistency of any size differences between the species.

\section{MATERIALS AND METHODS}

Adults of Chthamalus stellatus and C. montagui were collected at mid tide level at Tinside, Plymouth on 10 July 1984. Ripe egg masses were dissected from about 20 individuals of each species and placed in small Petri dishes to collect hatched larvae. Once hatched, the larvae were attracted to one side of the dish using a point light source and transferred with a wide bore pipette to the culture vessels. Culture techniques and food were based on those used for Chthamalus by Moyse (1963). Larvae were reared in covered, sterilized 1-1 containers without aeration or stirring. Food was provided by rearing the larvae in algal cultures consisting of three flagellates, Isochrysis galbana Parke, Hemiselmis rufescens Parke, and Prorocentrum micans Ehrenberg. Rearing medium was $700 \mathrm{ml}$ of quarter strength 'Erdschreiber' nutrients in $0.45 \mu \mathrm{m}$ filtered seawater. Cells of each species were added to give 1000 I. galbana, $500 \mathrm{H}$. rufescens and 20 P. micans per $\mathrm{mm}^{3}$. One Chthamalus larva was added to $5-15 \mathrm{ml}$ of medium. More algal cells were added only once in two of the cultures when cell counts were low. 
Paired cultures of C. montagui and C. stellatus were maintained in three different conditions to maximize the chances of successful development. Two pairs of cultures were kept in natural light: one exposed to direct sunlight (mean $22.6^{\circ} \mathrm{C}$, range $19.8-28.1^{\circ} \mathrm{C}$ ) and one in shade (mean $18.9^{\circ} \mathrm{C}$, range $16.8-20.3^{\circ} \mathrm{C}$ ). A third pair of cultures was kept at a constant $17.6^{\circ} \mathrm{C}, 1 \mathrm{~m}$ away from continuous illumination by two $40 \mathrm{~W}$ fluorescent tubes.

Between 10 and 30 larvae were removed from each culture at $3 \mathrm{~d}$ intervals to determine the stage of development of the populations of larvae and to provide specimens for measurement and morphological examination. A few drops of $5 \%$ chloral hydrate in seawater were added to relax the larvae. Measurements included total length (from the mid point of anterior shield margin to the tip of the dorsal thoracic spine or abdominal process, whichever longer), shield length (for stage IV onwards: anterior to posterior shield margin) and the width of the shield at its widest (behind the fronto-lateral horns). Differences in size of larvae between the two species at different stages and among cultures and plankton samples were tested using unreplicated three-way analysis of variance (ANOVA; Zar, 1984) of means of measurements for each stage for the two species in each rearing medium. Main effects of species, stage and source of

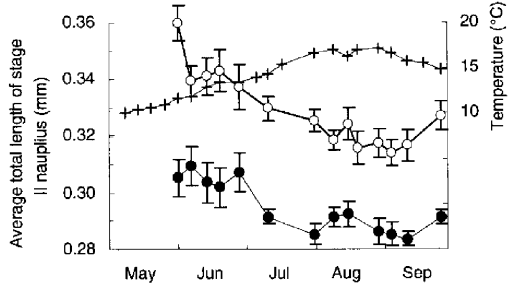

Figure 1. Changes in total length of stage II nauplii of Chthamalus stellatus $(\bigcirc)$ and $C$. montagui $(\mathbf{O})$ in plankton samples from Plymouth Sound in 1984. Values shown are means and $95 \%$ confidence intervals for samples of ten larvae per species per date. Weekly mean sea temperatures $(+)$ are also shown.

larvae and the interactions among these effects were tested against the residual variance, where this equals the three-way interaction term under the assumption that the three-way interaction is zero. Differences in shape were tested similarly.

Rate of development of the two species was measured as the time for $50 \%$ of the nauplii to reach any particular stage. This time was calculated using percentages in samples before and after the $50 \%$ point. For example, $30 \%$ reaching stage III by day 3 and $100 \%$ by day 6 gave an

Table 1. Sizes $(\mu \mathrm{m})$ of cyprid and nauplius larvae stages I-VI of Chthamalus montagui and C. stellatus from laboratory cultures (all data pooled) and from plankton samples. No stage I nauplii were present in plankton samples. Ratios of total lengths of naupliar stages between the species (TL G. s. /TL C. m.) and of shield length to shield width (SL/W) of naupliar stages within species are also shown.

\begin{tabular}{|c|c|c|c|c|c|c|c|c|c|}
\hline $\begin{array}{l}\text { Source/ } \\
\text { Species }\end{array}$ & $\begin{array}{l}\text { Naupliar } \\
\text { stage }\end{array}$ & $\begin{array}{l}\text { Total length } \\
(\mathrm{TL}) \\
\text { Mean } \pm \mathrm{SD}\end{array}$ & $\mathrm{N}$ & $\begin{array}{l}\text { Shield length } \\
\text { (SL) } \\
\text { Mean } \pm \text { SD }\end{array}$ & $\mathrm{N}$ & $\begin{array}{l}\text { Width }(\mathrm{W}) \\
\text { Mean } \pm \text { SD }\end{array}$ & $\mathrm{N}$ & $\mathrm{SL} / \mathrm{W}$ & $\begin{array}{l}\text { Ratio of TL } \\
\text { C. s. /C.m. }\end{array}$ \\
\hline \multicolumn{10}{|l|}{ Gultures } \\
\hline \multirow[t]{7}{*}{ C. montagui } & I & $204 \pm 5$ & 7 & - & - & $99 \pm 9$ & 7 & - & - \\
\hline & II & $299 \pm 15$ & 15 & - & - & $164 \pm 11$ & 11 & - & - \\
\hline & III & $333 \pm 10$ & 35 & - & - & $195 \pm 9$ & 36 & - & - \\
\hline & IV & $364 \pm 10$ & 31 & $252 \pm 7$ & 31 & $225 \pm 10$ & 27 & 1.12 & - \\
\hline & $\mathrm{V}$ & $389 \pm 17$ & 31 & $306 \pm 11$ & 31 & $272 \pm 12$ & 24 & 1.13 & - \\
\hline & VI & $464 \pm 19$ & 69 & $378 \pm 11$ & 72 & $329 \pm 14$ & 65 & 1.15 & - \\
\hline & cypris & $445 \pm 11$ & 17 & & & $215 \pm 7$ & 17 & & \\
\hline \multicolumn{10}{|l|}{ C.stellatus } \\
\hline & I & $213 \pm 11$ & 22 & - & - & $99 \pm 5$ & 22 & - & 1.04 \\
\hline & II & $319 \pm 10$ & 15 & - & - & $174 \pm 6$ & 14 & - & 1.07 \\
\hline & III & $372 \pm 12$ & 51 & - & - & $232 \pm 10$ & 53 & - & 1.12 \\
\hline & IV & $432 \pm 21$ & 45 & $289 \pm 13$ & 44 & $280 \pm 16$ & 45 & 1.03 & 1.19 \\
\hline & $\mathrm{V}$ & $508 \pm 17$ & 24 & $361 \pm 15$ & 31 & $340 \pm 15$ & 31 & 1.06 & 1.31 \\
\hline & VI & $612 \pm 26$ & 6 & $465 \pm 14$ & 6 & $413 \pm 8$ & 6 & 1.13 & 1.32 \\
\hline \multicolumn{10}{|c|}{$\begin{array}{l}\text { Plankton (stage } \\
\text { I not found) }\end{array}$} \\
\hline \multirow[t]{5}{*}{ C. montagui } & II & $301 \pm 9$ & 20 & - & - & $157 \pm 6$ & 20 & - & - \\
\hline & III & $331 \pm 14$ & 9 & - & - & $195 \pm 9$ & 9 & - & - \\
\hline & IV & $371 \pm 9$ & 9 & $255 \pm 10$ & 10 & $232 \pm 13$ & 9 & 1.10 & - \\
\hline & $\mathrm{V}$ & $396 \pm 26$ & 6 & $316 \pm 6$ & 8 & $277 \pm 14$ & 5 & 1.14 & - \\
\hline & VI & $498 \pm 23$ & 4 & $390 \pm 8$ & 7 & $335 \pm 12$ & 8 & 1.16 & \\
\hline \multirow[t]{5}{*}{ C.stellatus } & II & $330 \pm 13$ & 23 & - & - & $174 \pm 7$ & 22 & - & 1.10 \\
\hline & III & $388 \pm 21$ & 8 & - & - & $236 \pm 19$ & 8 & - & 1.17 \\
\hline & IV & $452 \pm 17$ & 5 & $299 \pm 16$ & 6 & $296 \pm 11$ & 6 & 1.01 & 1.22 \\
\hline & $\mathrm{V}$ & $559 \pm 13$ & 4 & $393 \pm 15$ & 9 & $381 \pm 18$ & 9 & 1.03 & 1.41 \\
\hline & VI & $574 \pm 0$ & 1 & $422 \pm 6$ & 2 & $394 \pm 41$ & 3 & 1.07 & 1.15 \\
\hline
\end{tabular}

C.s., Chthamalus stellatus; C.m., C. montagui. 
Table 2. Comparisons of the dimensions of Chthamalus montagui and C. stellatus larvae from cultures and from plankton samples taken in Fuly, 1984 by three-way analyses of variance. Variance associated with source of larvae was partitioned into two a priori contrasts.

\begin{tabular}{|c|c|c|c|c|c|c|c|c|c|}
\hline \multirow[b]{2}{*}{ Effect } & \multicolumn{3}{|c|}{ TL: III-V } & \multicolumn{3}{|c|}{$\mathrm{W}: \mathrm{III}-\mathrm{V}$} & \multicolumn{3}{|c|}{ SL: IV-V } \\
\hline & df & $F$ & $P$ & df & $F$ & $P$ & df & $F$ & $P$ \\
\hline Species & 1 & 150.8 & $<0.001$ & 1 & 256.7 & $<0.001$ & 1 & 213.63 & $<0.001$ \\
\hline Stage & 2 & 77.74 & $<0.001$ & 2 & 248.1 & $<0.001$ & 1 & 389.48 & $<0.001$ \\
\hline Source of larvae & 3 & 3.83 & 0.076 & 3 & 5.48 & 0.038 & 3 & 8.31 & 0.058 \\
\hline Contrast: culture vs plankton & 1 & 4.75 & 0.072 & 1 & 8.54 & 0.027 & 1 & 12.34 & 0.039 \\
\hline Contrast: among cultures & 2 & 3.37 & 0.104 & 2 & 3.96 & 0.080 & 2 & 6.30 & 0.084 \\
\hline Species by stage & 2 & 14.68 & 0.005 & 2 & 9.84 & 0.013 & 1 & 10.18 & 0.050 \\
\hline Species by source & 3 & 0.94 & 0.477 & 3 & 1.82 & 0.243 & 3 & 1.64 & 0.348 \\
\hline Stage by source & 6 & 0.83 & 0.585 & 6 & 2.17 & 0.185 & 3 & 2.56 & 0.230 \\
\hline $\begin{array}{l}\text { Residual (Species by stage } \\
\text { by source) }\end{array}$ & 6 & & & 6 & & & 3 & & \\
\hline
\end{tabular}

estimate of $3.8 \mathrm{~d}$ for $50 \%$ to reach stage III for C. montagui at $18.9^{\circ} \mathrm{C}$. Estimates were recorded to the nearest day.

Chthamalus larvae were also obtained from plankton samples taken weekly in Plymouth Sound from the beginning of June to the end of September in 1984. Changes in size of larvae released by adults through the summer were determined by measuring ten stage II nauplii of the two species in every sample. Specimens of naupliar stages II-VI were removed from plankton samples taken on 18 July 1984 (day 8 of the cultures) for further comparison with the larvae in cultures.

Morphological descriptions, including setation formulae, and figures were based on examination of several larvae of each stage from cultures and plankton. Terminology, abbreviations, and the formula for the setation used here follow those outlined by Lang (1979: after Sandison, 1967; Jones \& Crisp, 1954; Newman, 1965).

\section{RESULTS}

\section{Size}

The size of larvae of each naupliar stage is probably the simplest characteristic distinguishing the two species. Chthamalus stellatus is consistently larger than C. montagui in total length, shield length and shield width in both culture and in the plankton (Table 1). The difference in size between species increased with successive naupliar stages. In cultures average total length of stage I C. stellatus larvae was $104 \%$ that of C. montagui larvae but by stage VI average total length of $C$. stellatus larvae was $132 \%$ that of C. montagui larvae (Table 1).

Larvae of both species from the lowest temperature culture $\left(17.6^{\circ} \mathrm{C}\right)$ were larger than those from the highest temperature culture $\left(22.6^{\circ} \mathrm{C}\right)$. Analysis of variance (ANOVA) of measurements for naupliar stages III-V showed that differences in sizes among the cultures were not significant for any dimension (Table 2; source effect, among cultures contrast). Larvae from plankton samples were, however, significantly larger than those obtained in culture in both shield length and shield width (Table 2; source effect, cultures vs plankton contrast).

Nauplii released at the beginning of September were $\sim 10 \%$ smaller than those released in early June
(Figure 1). Differences in sizes among dates were highly significant in both species (one-way ANOVA: C. montagui, $F_{11,108}=9.82, P<0.001 ; C$. stellatus, $\left.F_{11,126}=5.33, P<0.001\right)$. Later naupliar stages were far less abundant and not present in sufficient numbers to permit a similar analysis.

\section{Shape of cephalic shield}

Chthamalus stellatus has a broader cephalic shield than C. montagui during stages II-VI (Figure 2A for C. montagui, Figure 2B for C. stellatus, Table 1). The shield of C. stellatus appears more circular in stages IV-VI than that of C. montagui. Chthamalus montagui tapers more towards the posterior shield margin which is consequently more convex than in the later stages of $C$. stellatus.

The ratio of shield length to width was significantly greater in C. montagui than in C. stellatus at all stages and under all conditions (Table 1; ANOVA, $F_{1,5}=21.44$, $P=0.005)$. There was no significant difference in shield length to width ratio of larvae in cultures compared to those in plankton samples. Shield length to width ratio was also not significantly changed by the different culture conditions.

\section{Dorsal thoracic spine and abdominal process}

The number and position of the abdominal spines are the same in both species at each stage (Figure 2). The abdominal process of stages $\mathrm{V}$ and VI is more slender and elongate in $C$. stellatus than the shorter, squatter process of C. montagui. The dorsal thoracic spine gets smaller relative to total length from stage IV-VI in C. montagui whereas its relative size is maintained in C. stellatus.

\section{Labrum}

The labrum is unilobed in both species (Figure 2). The shape of the labrum of the later stages is a good character for distinguishing the two species. In stages IV to VI the labrum of $C$. stellatus is almost parallel sided with a broad, straight distal end. In contrast the labrum of C. montagui at these stages is tapered towards the convex free end. A pair of large teeth at the corners of the free end are present from stage III onwards in both species. These are joined by 
(A)

(A) Chthamalus montagui
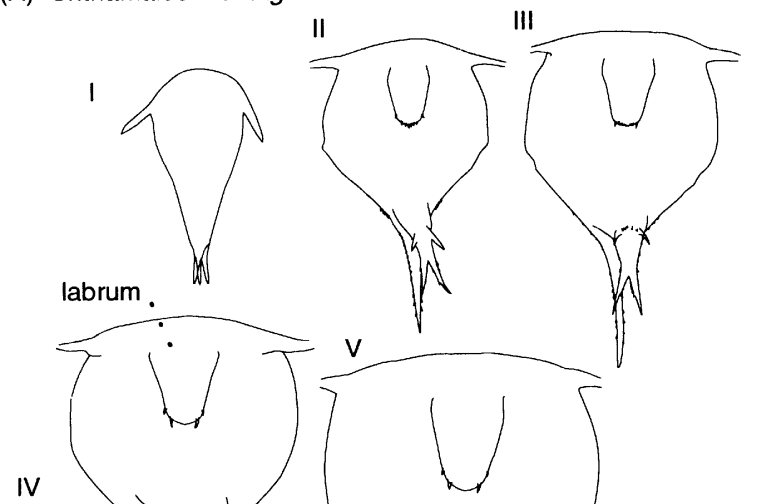

III

VI
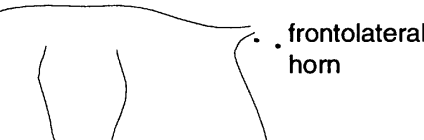

pigmented area
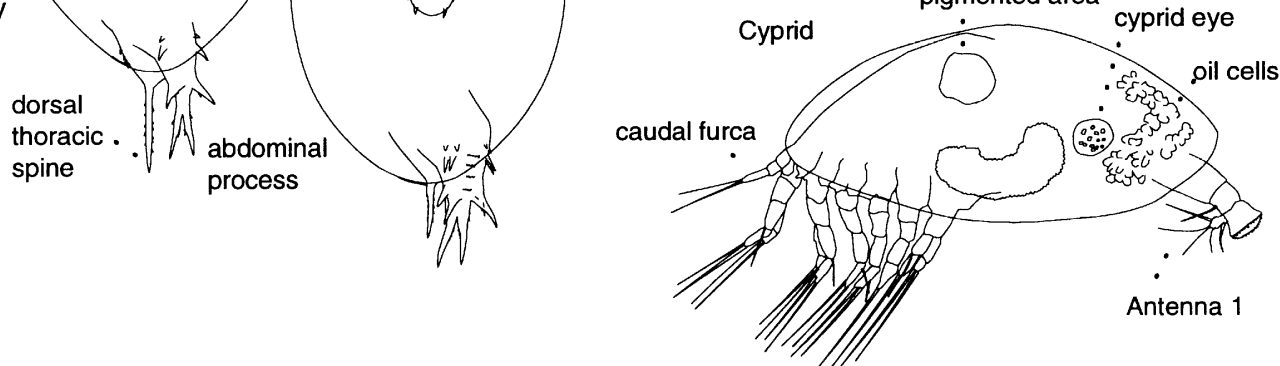

(B) Chthamalus stellatus

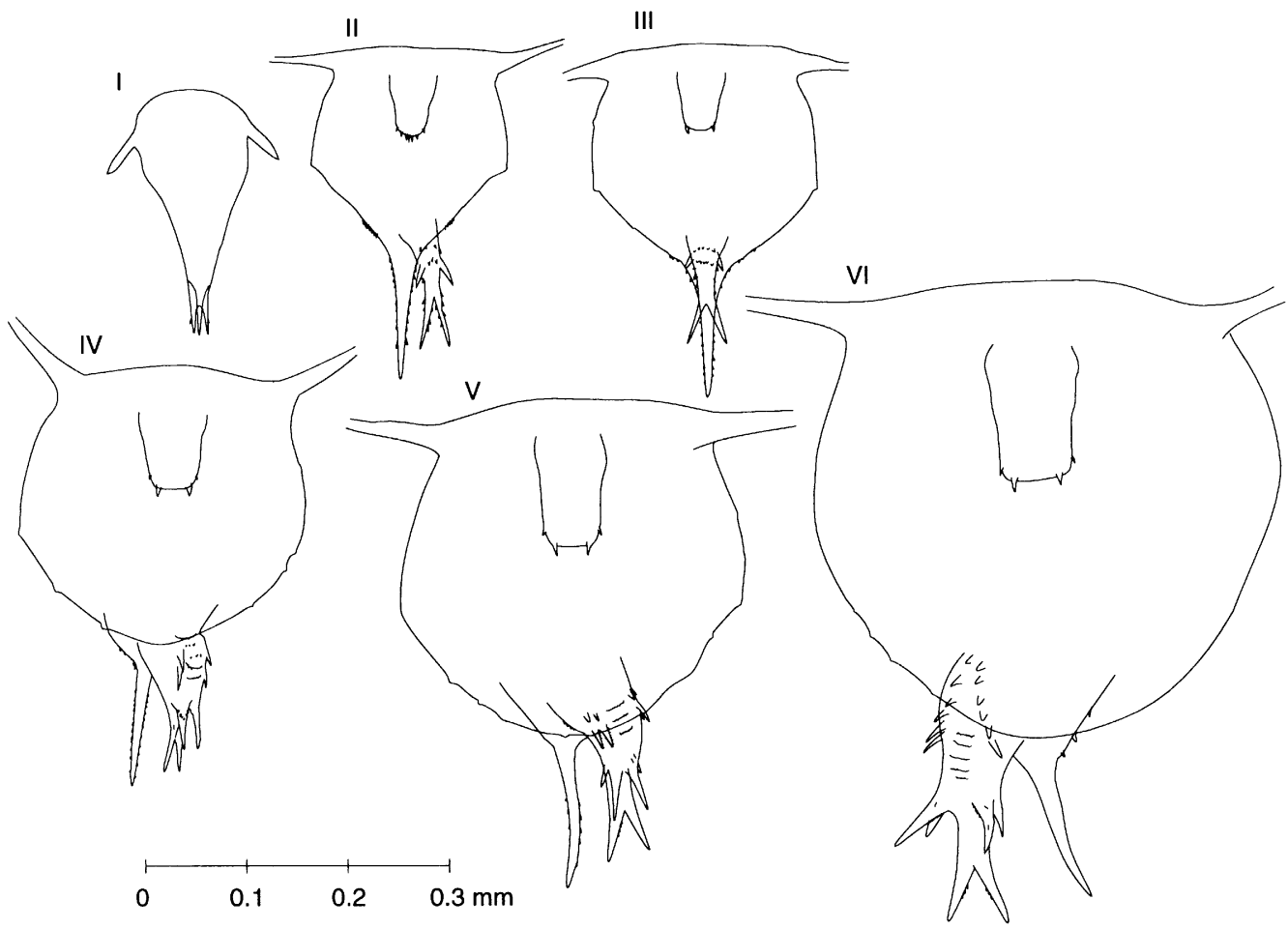

Figure 2. Naupliar stages I-VI of (A) Chthamalus montagui and (B) C. stellatus. The cyprid stage of C. montagui is also shown to the same scale.

a second, smaller, more lateral pair from stage IV onwards. All these teeth are larger and stouter in C. stellatus. The labrum of stage II has between four and seven large teeth at the distal end which are again stouter in C. stellatus. In all the stages of both species a row of inwardly pointing setae arise from near the margin of the labrum on its underside.

\section{Fointed appendages}

Apart from the appendages of C. stellatus being generally bigger, there are very few differences between the species (Figure 3, Table 3). Even individual setae, from the specialized hispid and cuspid setae to the simple setae, appear similar in shape but are scaled up in size in C. stellatus compared to C. montagui. The general patterns of increasing complexity of setation with development (Crisp, 1962) are followed in both species. Simple setae often become plumose in successive stages but never the reverse and setae are rarely lost.

The setation formulae of the limbs are given in Table 3. There are no differences in setation of the antennules between the species. Numbers and positions of the setae 
(A) Antenna 1
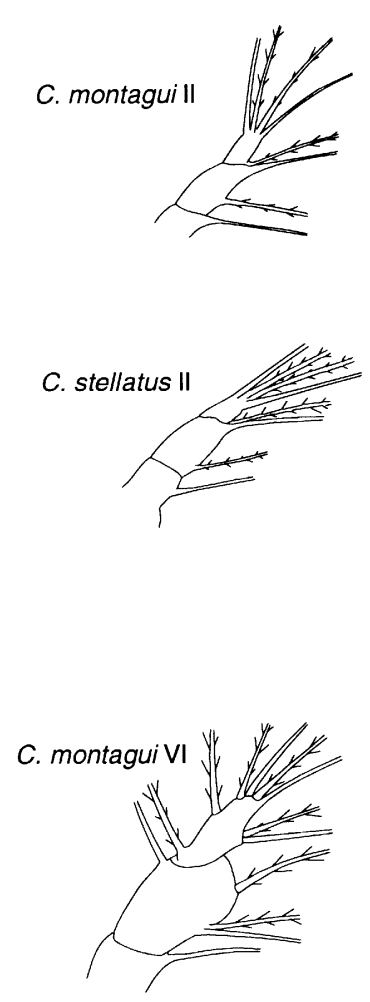

(B) Antenna 2
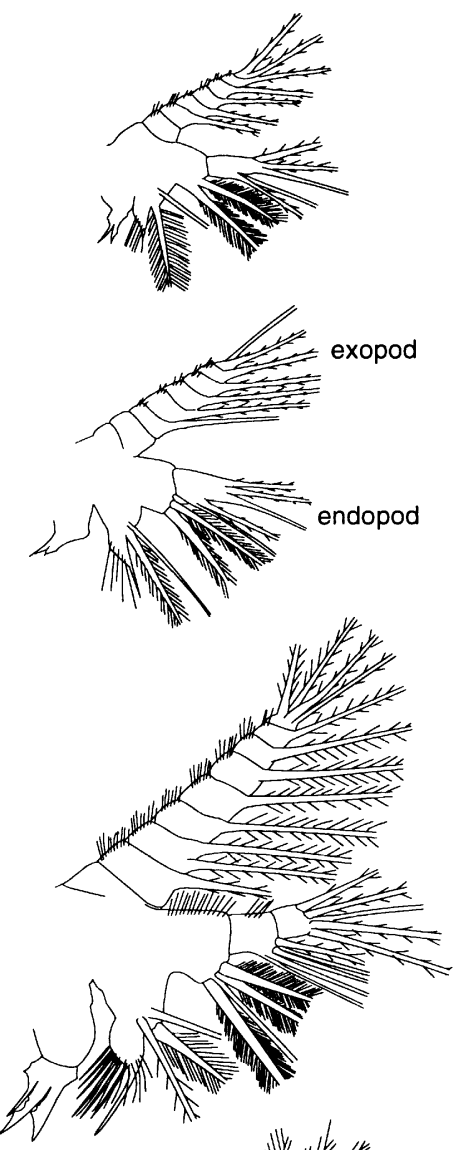

(C) Mandible
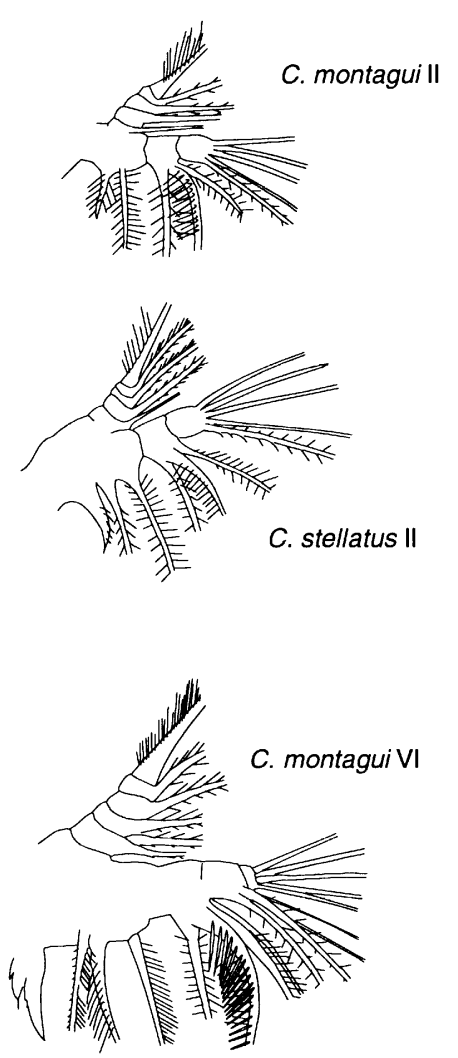

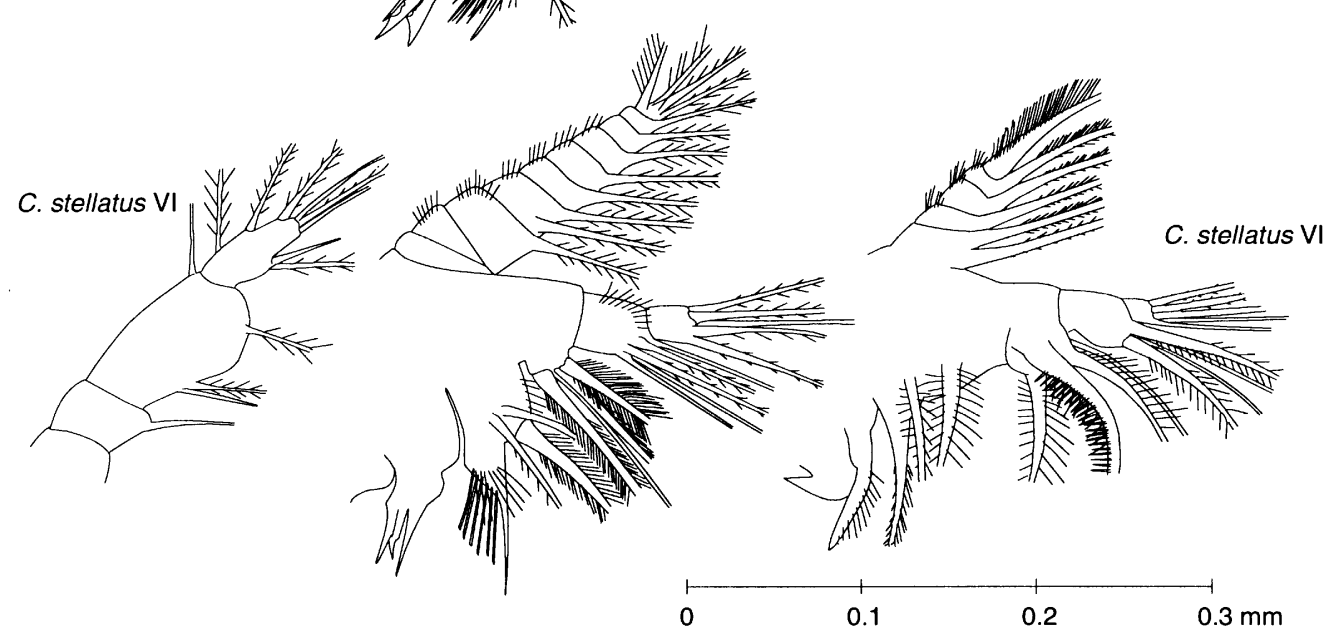

Figure 3. Naupliar stages II and VI of Chthamalus montagui and C. stellatus: (A) antenna 1 (antennule); (B) antenna 2 (antenna); and (C) mandible.

on the exopod of the antennae are also similar, although the antennae of $C$. stellatus stage II lack setules on the proximal and distal seta. There are some minor differences on the antennal endopod: stage III $C$. stellatus has two extra setae, stage IV C. stellatus has a plumose seta which is simple in C. montagui, and stage V and VI of C. stellatus each have a single plumose seta which is simple in C. montagui.

Differences in the setation of the mandibles of each species are minor. The exopod of the mandible in stage III has a simple seta in C. stellatus whose equivalent is plumose in C. montagui. The two distal setae on the endopod in stage VI are plumose in C. stellatus but simple in C. montagui.

\section{The cypris larva of Chthamalus montagui}

The cypris stage of C. montagui was produced under two of the three culture conditions and is shown in Figure 2. Chthamalus stellatus cyprids were not produced. Cyprids of either C. montagui or C. stellatus could not be recognized in the plankton samples because of the lack of known distinguishing morphological characters between the species and other species. Nauplii of Verruca stremia O.F. Müller, for example, present in large numbers in the plankton samples, have potentially similar sized cyprids (Pyefinch, 1948). However, if the relationship between the sizes of cultured and planktonic stage VI larvae is maintained in the cyprid then the $C$. montagui cyprids should 
Table 3. The setation formulae of Chthamalus stellatus and $\mathrm{C}$. montagui. The types of setae recognized follow those described by Lang (1979).

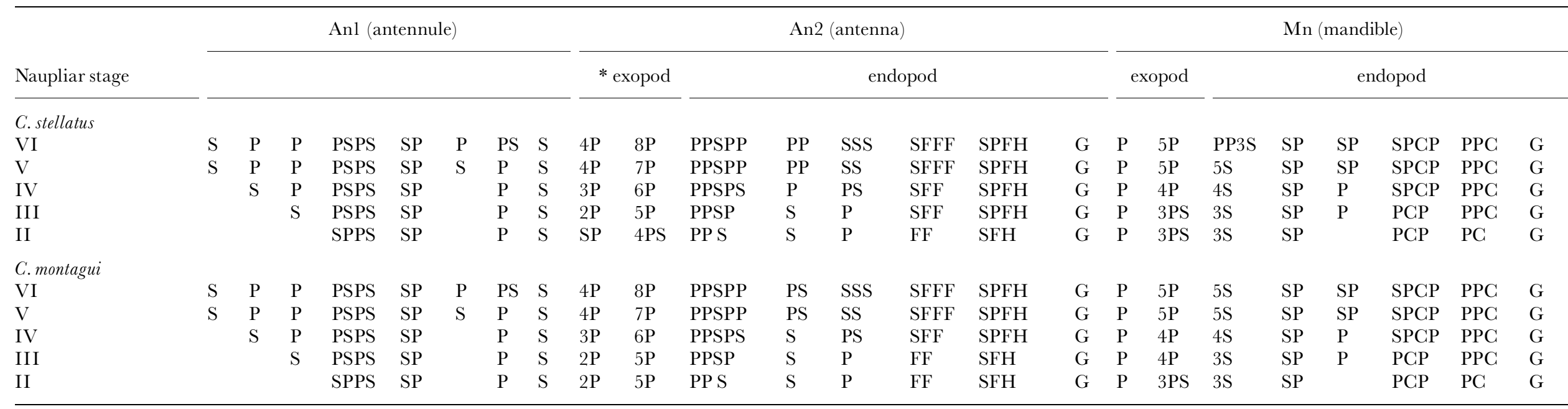

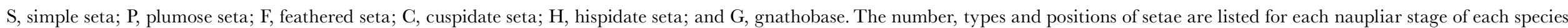
(excluding nauplius I) from the distal to the proximal ends of each appendage; *, (pre-axial) setae. 
Table 4. Estimates of the time in days for $50 \%$ of larvae to reach each larval stage of Chthamalus montagui and $\mathrm{C}$. stellatus in cultures.

\begin{tabular}{|c|c|c|c|c|c|c|}
\hline & \multicolumn{6}{|c|}{ Naupliar stage } \\
\hline & Culture temp. $\left({ }^{\circ} \mathrm{C}\right)$ & III & IV & $\mathrm{V}$ & VI & Cyprid \\
\hline \multirow[t]{3}{*}{ C. montagui } & 17.6 & 4 & 8 & 10 & 13 & - \\
\hline & 18.9 & 4 & 7 & 8 & 11 & 14 \\
\hline & 22.6 & 3 & 5 & 9 & 11 & 17 \\
\hline \multirow[t]{3}{*}{ C. stellatus } & 17.6 & 5 & 12 & 17 & - & - \\
\hline & 18.9 & 5 & 9 & 12 & 16 & - \\
\hline & 22.6 & 4 & 5 & 13 & 15 & - \\
\hline
\end{tabular}

have a total length of about $0.46 \mathrm{~mm}$. Similarly, if the same difference in size between the species exists at the cyprid stage as for stage VI nauplii then the cyprids of C. stellatus in the sea should have a shield length of $0.58 \mathrm{~mm}$. Size should therefore be the most reliable character to separate the two Chthamalus species in Britain, once they are recognized as belonging to this genus.

\section{Rates of development in culture}

The rates of development of C. montagui and C. stellatus in the three culture conditions are shown in Table 4. Larvae of C. stellatus reached stage $\mathrm{V}$ in 12 to 17 days compared to 8 to 10 days for $C$. montagui, equivalent to extra development time of 45 to $70 \%$. No statistical analysis of development times was attempted because cultures were not replicated at each of the environmental conditions. There was some evidence that response of development rate to temperature was different in the two species. Chthamalus stellatus larvae developed to stage $\mathrm{V}$ over a $70 \%$ longer period than C. montagui at $17.6{ }^{\circ} \mathrm{C}$, whereas at $22.6{ }^{\circ} \mathrm{C}$ the interspecific difference was only $45 \%$.

\section{DISCUSSION}

Comparison of the larvae described here with previous studies of Chthamalus species in Europe reveals the previous descriptions as being of either C. montagui or C. stellatus. Sizes of larvae given by Bassindale (1936) are very close to measurements of $C$. montagui in this study, whereas those of Le Reste (1965) are very close to those of $C$. stellatus. The overall shape of the cephalic shield and the tapered labrum in Bassindale's (1936) description are also similar to those of C. montagui in this study. Le Reste's (1965) descriptions of the stage II nauplius would appear to be based on C. stellatus. Previously reported setation formulae are similar to this study for both species (Bassindale, 1936). Groom's (1894) description of stage II larvae of Chthamalus is less easily ascribed to either species, although the dimensions (TL $0.32 \mathrm{~mm}$ ) and prominent postero-lateral shield marginal spines suggest the material was probably $C$. stellatus. The larvae used by Moyse (1963) were probably of C. montagui from the dimensions and development times quoted. Although no distinction between the cyprids of the two species was possible in this study, measurements of newly-settled Chthamalus cyprids in the south-west of Ireland show a strongly bimodal size distribution (O'Riordan et al., 1999). The peaks in the distribution correspond well to the estimates of 0.46 and $0.58 \mathrm{~mm}$ produced here for cyprids of C. montagui and C. stellatus.

Naupliar size and larval life history patterns in barnacles are closely related. Amongst summer breeding barnacles, oceanic species and those from exposed coasts tend to have larger larvae (e.g. Lepas anatifera, Moyse, 1963; Pollicipes polymerus, Lewis, 1975). In contrast, those which inhabit more sheltered conditions have smaller larvae (e.g. Elminius modestus, Knight-Jones \& Waugh, 1949; Balanus improvisus, Jones \& Crisp, 1954). The larger size has been proposed as an adaptation to a longer planktonic phase (Moyse, 1963).

While the size of larvae of both species changed during the breeding season (variable dependent on latitude, May-October in south-western Britain, Burrows et al., 1992; O'Riordan et al., 1995), C. stellatus larvae were consistently larger than C. montagui larvae throughout the period of release. Variation in size of larvae within species has been ascribed to the feeding conditions of the parental adults (Semibalanus balanoides, Barnes, 1953). Low shore individuals of $C$. montagui and C. stellatus begin to breed before those higher on the shore (Burrows et al. 1992). Early stage II nauplii may come mainly from lower shore populations where feeding conditions may be better (embryos for culture in this study were collected from mid shore adults). Larval size has most often, however, been correlated with temperature during oogenesis and embryonic development. Latitudinal differences have been found in the size of larvae of $S$. balanoides, with larger larvae being found in colder waters (Barnes \& Barnes, 1965). Sacculina carcini (natural conditions: Walker, 1988) and C. montagui (laboratory conditions: Patel \& Crisp, 1960) produce larger larvae at lower temperatures. Changes in size of newly released C. montagui and C. stellatus larvae (stage II) in plankton samples taken throughout the summer are most probably due to a similar effect of temperature. Later nauplius stages (IIIVI) of C. montagui and $C$. stellatus larvae among the cultures showed relatively little variation in size over the limited temperature range provided.

The longer development time for larvae of C. stellatus compared to C. montagui has important consequences for the ecology and dispersal of the two species. Duration in cultures is affected by food (Moyse, 1963; Lang, 1976, 1979; Lang \& Marcy, 1982) and temperature (Scheltema \& Williams, 1982; West, 1982). The lack of effects of temperature on duration in this study probably reflects the narrow range of temperatures used. Development time in cultures may, however, be less than that in natural conditions. From the first release of nauplii in 
early May (Burrows et al., 1992) to the first observed settling cyprids in early to mid July (Southward, 1976) is at least $75 \mathrm{~d}$, much longer than the two weeks for complete development of C. montagui larvae in this study. Larvae may either develop more slowly or fail to survive the lower temperatures in the early part of the breeding season in Britain (Southward, 1976). Reduced temperatures and consequent effects of rates and success of larval development may also account for the greater yearly variation in larval settlement at the northern limits of the two species.

The ratio of the cubes of shield length of larvae in culture suggests the mass of stage VI C. stellatus larvae may be $190 \%$ that of C. montagui. More stored energy as body mass and in the form of oil cells (West, 1982) in the cyprid (Figure 2) may allow C. stellatus to extend the 'competent' phase (Crisp, 1974) of the cypris and increase the chances of finding a suitable site for settlement. The predominance of $C$. stellatus in the fragmented habitats of headlands and islands may require a greater ability of the larvae to traverse stretches of unsuitable areas.

Size may not be the only adaptation of $C$. stellatus larvae to a longer planktonic life. The long frontolateral horns, the broader and flatter cephalic shield, the retention of the dorsal thoracic spine in the later stages and the longer, more slender abdominal process all increase the surface to volume ratio of the larva, and therefore reduce its sinking rate. A slower sinking rate would reduce energy costs of swimming to maintain optimal depth. This saving in energy should allow a longer search for a suitable substrate (Lucas et al., 1979). In contrast, the differences between the species in the appendages and their setation are small and minor. It is difficult to see how these small differences could represent adaptations to very different planktonic environments (Crisp et al., 1981) or allow use of different sized food particles. Further work on the spacing and arrangement of setules using scanning electron microscopy and the feeding behaviour of the two species would be useful (Rainbow \& Walker, 1976).

The most obvious difference in feeding structures is between the labra of the two species. The larger size and stouter teeth in the later stages (IV-VI) of C. stellatus may allow this species to puncture and feed on larger, harder food items. This may be analogous to the presence of conical spines on the base of the anterior ramus of cirrus I in C. stellatus adults (Southward, 1976). These spines have been proposed to have a similar function (Crisp et al., 1981).

Larval morphology has been regarded as an indicator of phylogenetic relationships among the barnacles, and there is a consensus that the larvae of the Chthamalinae sensu stricto show resemblances to pollicipoid larvae (Lewis, 1975; Lang, 1979; Egan \& Anderson, 1989; Miller et al., 1989). Adult morphology suggests an origin of sessile barnacles from an ancestral stem close to pollicipoid scalpellomorphs, but it is not clear whether the verrucomorphs constitute a separate clade, and where the rest of the former Chthamaloidea, less the Chthamalinae, fit in (Newman \& Ross, 1976; Newman, 1987; Newman \& Hessler, 1989; Glenner et al., 1995). Molecular data confirm an origin of the balanomorph groups from a scalpellid ancestor (Applegate et al., 1991). The interesting thing from our results is the considerable morphological differences between the larvae of $C$. stellatus and C. montagui. Dando \& Southward (1980) regarded the differences between the adults of these species, particularly the isozyme differences, as of subgeneric value. However, a subgeneric status was also suggested for other groups of Chthamalus. For this reason it is surprising that Miller et al. (1989) found no differences between the larvae of $C$. dalli, with which Dando \& Southward (1980) grouped C. montagui, and those of C. fissus, grouped with other warm-water tropical species found on both sides of the Isthmus of Panama. The most distinct larval character of $C$. stellatus, which separates it from the other species whose larvae have been described-C. montagui, C. fissus, C. dalli, C. fragilis, C. dentatus and C. antennatus (Miller et al., 1989; Lang, 1979; Achituv, 1986; Egan \& Anderson, 1989) - is the broad and flat-edged labrum. From this it might be inferred that $C$. stellatus lies closer to the main stem of the balanomorphs than the other chthamaline species. However, it is also possible that the shape of the labrum and the broader form of the cephalic shield could be specializations to an oceanic life. Evidence of larval morphology needs to be sought from other species grouped with $C$. stellatus that also have an oceanic distribution, such as $C$. angustitergum.

Inocula for the algal cultures came from the Plymouth Culture Collection, Marine Biological Association. Temperature data for Plymouth Sound were provided by the Environmental Health Officer, Plymouth City Council. A.J.S. is indebted to Dr W.A. Newman for discussions. M.T.B. was supported by a research studentship from the Natural Environment Research Council, GR3/4 ALS26. We would like to thank Todd Minchinton and an anonymous referee for comments that substantially improved the manuscript.

\section{REFERENCES}

Achituv, Y., 1986. The larval development of Chthamalus dentatus Krauss (Cirripedia) from South Africa. Crustaceana, 51, 259 269.

Applegate, M., Abele, L.G. \& Spears, T., 1991. A phylogenetic study of the Cirripedia based on 18S ribosomal DNA sequences. American Zoologist, 31, 104A.

Barnes, H., 1953. Size variations in the cyprids of some common barnacles. Fournal of the Marine Biological Association of the United Kingdom, 32, 297-304.

Barnes, H. \& Barnes, M., 1965. Egg size, nauplius size and their variation with local, geographical and specific factors in some common cirripedes. Fournal of Animal Ecology, 34, 391-402.

Bassindale, R., 1936. The developmental stages of three English barnacles, Balanus balanoides (Linn.), Chthamalus stellatus (Poli), and Verruca stroemia (O.F. Müller). Proceedings of the Zoological Society of London, 106, 57-74.

Burrows, M.T., 1988. The comparative biology of Chthamalus stellatus (Poli) and Chthamalus montagui Southward. $\mathrm{PhD}$ thesis, University of Manchester.

Burrows, M.T., Hawkins, S.J. \& Southward, A.J., 1992. A comparison of reproduction in co-occurring chthamalid barnacles, Chthamalus stellatus (Poli) and Chthamalus montagui Southward. Fournal of Experimental Marine Biology and Ecology, 160, 229-249.

Crisp, D.J., 1962. The planktonic stages of the cirripedia Balanus balanoides (L.) and Balanus balanus (L.) from north temperate waters. Crustaceana, 3, 207-221. 
Crisp, D.J., 1974. Factors influencing the settlement of marine invertebrate larvae. In Chemoreception in marine organisms (ed. P.T. Grant and A.M. Mackie), pp.177-265. London: Academic Press.

Crisp, D.J., Southward, A.J., \& Southward, E.C., 1981. On the distribution of the intertidal barnacles Chthamalus stellatus, Chthamalus montagui and Euraphia depressa. Fournal of the Marine Biological Association of the United Kingdom, 61, 359-380.

Dando, P.R. \& Southward, A.J., 1980. A new species of Chthamalus (Crustacea: Cirripedia) characterized by enzyme electrophoresis and shell morphology: with a revision of other species of Chthamalus from the western shores of the Atlantic Ocean. Fournal of the Marine Biological Association of the United Kingdom, 60, 787-831.

Darwin, C.R., 1854. A monograph on the sub-class Cirripedia with figures of all the species. The Balanidae, (or sessile cirripedes); the Verrucidae; etc., etc., etc. London: Ray Society.

Egan, E.A. \& Anderson, D.T., 1989. Larval development of the chthamaloid barnacles Catomerus polymerus Darwin, Chamaesipho tasmanica Foster \& Anderson and Chthamalus antennatus Darwin (Crustacea: Cirripedia). Zoological Journal of the Linnaean Society, 95, 1-28.

Glenner, H., Grygier, M.J., Høeg, J.T., Jensen, P.G. \& Schram, F.R., 1995. Cladistic analysis of the Cirripedia Thoracica. Zoological Journal of the Linnaean Society, 114, 365-404.

Groom, T.T., 1894. On the early development of the Cirripedia. Philosophical Transactions of the Royal Society of London B, 185, 119-232.

Jensen, P.G., Moyse, J., Høeg, J. \& Alyahya, H., 1994. Comparative SEM studies of lattice organs - putative sensory structures on the carapace of larvae from Ascothoracida and Cirripedia (Crustacea Maxillopoda Thecostraca). Acta Zoologica, 75, 125-142.

Jones, L.W.G. \& Crisp, D.J., 1954. The larval stages of the barnacle Balanus improvisus Darwin. Proceedings of the Zoological Society of London, 123, 765-780.

Knight-Jones, E.W. \& Waugh, G.D., 1949. On the larval development of Elminius modestus. Fournal of the Marine Biological Association of the United Kingdom, 28, 413-438.

Lang, W.H., 1976. The larval development and metamorphosis of the pedunculate barnacle Octolasmis mulleri (Coker, 1902) reared in the laboratory. Biological Bulletin. Marine Biological Laboratory, Woods Hole, 150, 255-267.

Lang, W.H., 1979. Larval development of shallow water barnacles of the Carolinas (Cirripedia: Thoracica) with keys to the naupliar stages. NOAA Technical Report NMFS, 421, 1-39.

Lang, W.H. \& Marcy, M., 1982. Some effects of early starvation on the survival and development of barnacle nauplii, Balanus improvisus (Darwin). Fournal of Experimental Marine Biology and Ecology, 60, 63-70.

Le Reste, L., 1965. Contribution a l'étude des larves de cirripedes dans le Golfe de Marseilles. Receuil des Travaux de la Station Marine d'Endoume, 38, 33-121.

Lewis, C.A., 1975. Development of the gooseneck barnacle Pollicipes polymerus (Cirripedia: Lepadomorpha): fertilisation through settlement. Marine Biology, 32, 141-153.

Lucas, M.I., Walker, G., Holland, D.L. \& Crisp, D.J., 1979. An energy budget for the free swimming and metamorphosing cypris larva of Balanus balanoides (Crustacea: Cirripedia). Marine Biology, 55, 221-229.

Miller, K.M., Blower, S.M., Hedgecock, D. \& Roughgarden, J., 1989. A comparison of the larval and adult stages of
Chthamalus dalli and Chthamalus fissus (Cirripedia: Thoracica). Fournal of Crustacean Biology, 9, 242-256.

Moyse, J., 1963. A comparison of the value of various flagellates and diatoms as food for barnacle larvae. Fournal du Conseil, 28, 175-187.

Newman, W.A., 1965. Prospectus on larval cirriped setation formula. Crustaceana, 9, 51-56.

Newman, W.A., 1987. Evolution of cirripedes and their major groups. Crustacean Issues, 5, 3-42.

Newman, W.A. \& Hessler, R.R., 1989. A new abyssal hydrothermal verrucomorphan (Cirripedia; Sessilia): the most primitive living sessile barnacle. Transactions of the San Diego Society of Natural History, 21, 259-273.

Newman, W.A. \& Ross, A., 1976. Revision of the balanomorph barnacles: including a catalog of the species. Memoirs of the San Diego Society of Natural History, 9, 1-108.

O'Riordan, R.M., Myers, A.A. \& Cross, T.F., 1995. The reproductive cycles of Chthamalus stellatus (Poli) and C. montagui Southward in south-western Ireland. Fournal of Experimental Marine Biology and Ecology, 190, 17-38.

O'Riordan, R.M., Myers, A.A., McGrath, D., Delany, J. \& Power, A.-M., 1999. The sizes at settlement in natural populations of the cyprids of Chthamalus montagui and C. stellatus. Fournal of the Marine Biological Association of the United Kingdom, in press.

Patel, B. \& Crisp, D.J., 1960. The influence of temperature on the breeding and moulting activities of some warm-water species of operculate barnacles. Fournal of the Marine Biological Association of the United Kingdom, 39, 667-680.

Pyefinch, K.A., 1948. Methods of identification of the larvae of Balanus balanoides (L.), Balanus crenatus Brug. and Verruca stroemia O.F. Müller. Fournal of the Marine Biological Association of the United Kingdom, 27, 451-463.

Rainbow, P.S. \& Walker, G., 1976. The feeding apparatus of the barnacle nauplius larva: a scanning electron microscope study. Fournal of the Marine Biological Association of the United Kingdom, 56, 321-326.

Sandison, E.E., 1967. The naupliar stages of Balanus pallidus stutsberi Darwin and Chthamalus aestuarii Stubbings (Cirripedia: Thoracica). Crustaceana, 13, 161-174.

Scheltema, R.S. \& Williams, I.P., 1982. Significance of temperature to larval survival and length of development in Balanus eburneus (Crustacea: Cirripedia). Marine Ecology Progress Series, 9, 43-49.

Southward, A.J., 1976. On the taxonomic status and distribution of Chthamalus stellatus (Cirripedia) in the north-east Atlantic region: with a key to the common intertidal barnacles of Britain. Fournal of the Marine Biological Association of the United Kingdom, 56, 1007-1028.

Walker, G., 1988. Observations on the larval development of Sacculina carcini (Crustacea: Cirripedia: Rhizocephala). Journal of the Marine Biological Association of the United Kingdom, 68, 377-390.

West, T.L., 1982. Growth and development in the larvae of Balanus eburneus Gould (Cirripedia: Thoracica). $\mathrm{PhD}$ thesis, Duke University, USA.

Zar, J.H., 1984. Biostatistical analysis. New Jersey: Prentice-Hall.

Submitted 14 April 1997. Accepted 23 February 1998. 
